$\begin{array}{ll}\text { Volume } & : 06 \\ \text { Nomor } & : 02 \\ \text { Bulan } & : \text { Mei } \\ \text { Tahun } & : 2020 \\ \text { http } & : \text { //ejurnal.pps.ung.ac.id/index.php/AKSARA/index }\end{array}$

\title{
Analisis Penyelesaian Sengketa Akad Murabahah (Jual-Beli) Antara Bank Syariah - X dengan PT AS di Badan Arbitrase Syariah Nasional -Majelis Ulama Indonesia (BASYARNAS-MUI)
}

\author{
Mohamad Nur \\ Dosen, PPKN, STKIP-Kusuma Negara \\ mohamadnur@stkipkusumanegara.ac.id
}

Received: 23 Februari 2020; Revised: 27 April 2020; Accepted: 28 April 2020

DOI: http://dx.doi.org/10.37905/aksara.6.2.161-170.2020

\begin{abstract}
ABSTRAK
Salah satu contoh kasus sengketa di Basyarnas yang terjadi antara dua pihak (BS X dan PT AS) telah melakukan perjanjian pembiayaan murabahah (jual-beli) dan masalah utama bersumber dari perjanjian/akadnya, kedua belah pihak sepakat menyelesaikan sengketa sesuai ketentuan beracara di Basyarnas. Metode penelitian yang digunakan ini adalah penelitian kualitatif dengan pendekatan penelitian yuridis normatif yaitu penelitian ini mengacu dan berbasis pada analisa norma hukum dengan tujuan untuk menemukan kebenaran berdasarkan logika keilmuan dari sisi normatifnya. Penelitian ini menekankan pada penggunaan norma hukum secara tertulis serta didukung dengan hasil wawancara dengan beberapa narasumber. Metode arbiter Basyarnas dalam memutus sengketa akad murabahah antara BS X dengan PT AS dilakukan dengan memeriksa alat bukti, keterangan saksi, keyakinan arbiter, menganalisa gugatan secara lengkap, meferifikasi, memeriksa dengan teliti, cermat, mengungkapkan fakta secara hati-hati serta mempunyai keyakinan yang kuat sebagai bahan pertimbangan hukum dalam memutus perkara secara adil dan sesuai ketentuan syariah. Menegakkan asas keadilan dengan mempehatikan hak-hak yang sesuai dengan prinsip keadilan yang universal terhadap semua pihak sesuai dengan tujuan untuk menyelesaikan sengketa dengan adil para arbiter mempunyai latar belakang keahlian, antara lain; berlatang belakang sarjana hukum, sarjana syariah dan praktisi bank syariah yang telah berpengalaman.
\end{abstract}

\section{Kata Kunci:}

Sengketa, Murabahah, Metode arbiter.

\section{PENDAHULUAN}

Manusia dalam kehidupan kesehariannya tidak terlepas dengan kegiatan ekonomi. Kegiatan ekonomi merupakan aktifitas dalam mencari harta dan menjadi kebutuhan yang pokok dalam kehidupan keseharian. Dalam kegiatan ekonomi tersebut, itu diperlukan aturan dan nilai-nilai yang membimbing manusia dalam kegiatan transaksi bisnisnya. Manusia yang ditugaskan untuk memimpin, mengabdi dan sebagai hamba Allah di dunia telah diberikan aturan dalam semua hal termasuk masalah terntang harta dan ekonomi. Pandangan Islam terhadap harta dan ekonomi, secara umum, tugas kehalifan manusia adalah tugas mewujudkan kemakmuran dan kesejahteraan dalam hidup dan kehidupan, serta tugas pengabdian atau ibadah dalam arti luas. Untuk menunaikan tugas tersebut Allah SWT memberi manusia dua anugrah nikmat utama, yaitu manhaj al-hayat 'sistem kehidupan' dan wasilah al hayat 'sarana kehidupan'. Manhaj al-hayat adalah seluruh aturan 


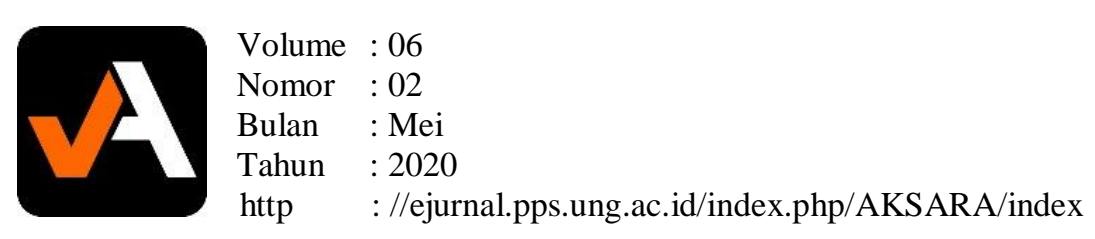

kehidupan manusia yang bersumber kepada al-Quran dan Sunnah Rasul. Aturan tersebut berbentuk keharusan melakukan atau sebaiknya melakukan sesuatu, juga dalam bentuk larangan melakukan atau sebaliknya meninggalkan sesuatu. Aturan tersebut dikenal sebagai hukum lima, yakni wajib, sunnah, mubah, makruh atau haram. Aturan tersebut dimaksudkan untuk menjamin keselamatan manusia sepanjang hidupnya, baik yang menyangkut keselamatan agama, keselamatan diri (jiwa dan raga), keselamatan akal, keselamatan harta benda, maupun keselamatan nasab keturunan. Hal tersebut merupakan kebutuhan pokok atau primer (al-haajat adh-dharuriyyah). (M.Syafii Antonio, 2001:7).

Rendahnya nilai dan moral dalam dunia bisnis menjadi salah satu problematika serius yang dapat membahayakan transaksi-transaksi bisnis yang dilakakuan para pebisnis. (Husain Sahatah dan Siddiq Muh Al Amin Adh Dhahir, 2005:15) Problematika yang terjadi dalam dunia bisnis diakibatkan oleh dominasi konsep materialisme atas nilai-nilai spiritualime dalam kegiatan ekonomi. Konsep-konsep materialialistik menjangkau lebih besar dunia ekonomi dan bisnis dibandingkan dengan konsep nilai-nilai spiritual saat ini. Berbagai masalah psikologi dan sosial bagi pelaku bisnis didasarkan pada kekurangan mereka terhadap prinsip-prinsip moral dan identitas (muslim). Masalah seringkali timbul, namun teori dan hukum bisnis gagal menanggulangi hal itu, para pakar teori bisnis menekankan pentinya kembali kepada moral dan perlunya menyeimbangkan kode etik bisnis. (Husain Sahatah \& Siddiq Muh Al Amin Adh Dhahir, 2005: 22). Dalam kegiatan ekonomi memerlukan aturan dan nilai-nilai yang membimbing manusia dalam kegiatan transaksi bisnis. Allah SWT. telah memberikan petunjuk melalui para rasul-Nya. Petunjuk itu meliputi semua yang ada dalam al-Qur'an, baik aqidah, ahklak dan syariah. Untuk aqidah dan akhlak bersifat tetap. Adapun syariah senantiasa berubah sesuai dengan kebutuhan dan perkembangan zaman. Karena itu syariah Islam mempunyai sifat yang komprehensif dan universal. Disebut komprenshif karena mencakup seluruh aspek kehidupan, baik ibadah yang behubungan dengan Allah maupun hubungan dengan antar sesama manusia atau muamalah. Sedangkan sifat universal oleh karena tidak terbatas pada waktu tertentu saja dan tidak terbatas pada tempat tertentu saja sehingga dapat diterapkan dalam setiap waktu dan setiap zaman. Makna universalitas terlihat dalam kegiatan dibidang muamalah terutama disektor ekonomi.

Di dalam hukum muamalah Islam mempunyai prinsip yang dapat dirumuskan yaitu, Pada dasarnya segala bentuk muamalah adalah mubah, kecuali yang ditentukan lain oleh Al Quran dan Sunnah Rasul. Muamalat dilakukan atas dasar sukarela, tanpa mengandung unsur-unsur paksaan. Muamalat dilakukan atas dasar pertimbangan mendatangkan manfaat dan menghindari madharat dalam hidup masyarakat. (Ahmad Azhar Basyir,2000:15)

Salah satu kegiatan bermuamalah dalam keuangan Islam adalah perbankan syariah. Bank Syariah merupakan istilah yang dikenal dan dikembangkan dalam perbankan di Indonesia. Sementara di negara lain, istilah tersebut dikenal dengan nama Bank Islam (Islamic Bank). Penyebutan bank syariah mempunyai latar belakang beberapa alasan, baik hukum, politik, dan sosiologis. Latar belakang penyebutan tersebut, antara lain pengaruh perkembangan ekonomi di Indonesia. Dalam praktek operasional di bank syariah memmpunyai risiko hukum. Salah satu risiko hukum adalah adanya gugatan dari nasabah yang mengakibatkan sengketa. Permasalahan yang sering terjadi adalah karena masalah akad yang belum dipahami oleh para pihak dan tidak menjalankan ketentuan standar operasional dan prosdur di bank syariah. Produk yang paling banyak digunakan adalah dengan akad murabahah atau jual beli. 


\section{KAJIAN PUSTAKA Sengketa}

Sengketa menurut kamus besar bahasa Indonesia, sengketa adalah segala sesuatu yang menyebabkan perbedaan pendapat, pertikain atau perbantahan. Konflik atau sengketa adalah sesuatu yang menyebabkan perbedaan pendapat antara dua pihak atau lebih yang berselisih perkara dalam pengadilan. Konflik atau sengketa terjadi juga karena adanya perbedaan persepsi yang merupakan penggambaran tentang lingkungan yang dilakukan secara sadar yang didasari pengetahuan yang dimiliki seseorang, lingkungan yang dimaksud adalah lingkungan fisik maupun sosial, demikian menurut Koentjaraningrat. (Sudarsono,2002:433).

Kata sengketa, perselisihan, pertentangan di dalam Bahasa Inggris sama dengan "conflict" atau "dispute". (Koentjaraningrat,1982:103). Keduanya mengandung pengertian tentang adanya perbedaan kepentingan diantara kedua belah pihak atau lebih, tetapi keduanya dapat dibedakan. Kosa kata "conflict" dalam bahasa Indonesia diserap menjadi konflik, sedangkan kosa kata "dispute” diterjemahkan dengan kata sengketa. (John.M. Echlosdan Hasan Shadily, 1996:138).

Pengertian Konflik itu sendiri dirumuskan oleh Dean G. Pruitt dan Jeffrey Z. Rubin bahwa, konflik adalah persepsi mengenai perbedaan kepentingan (perceived divergence of interest), atau suatu kepercayaan bahwa aspirasi pihak-pihak yang berkonflik tidak dicapai secara simultan (secara serentak). Pruitt dan Rubin lebih lanjut melihat konflik dari perbedaan kepentingan atau tidak dicapainya kesepakatan para pihak. Maksud Perbedaan kepentingan adalah berlainannya keperluan atau kebutuhan masing-masing pihak. (HS. Salim, 2010:82) Perihal Teori Konflik, menurut Salim HS, dapat digolongkan atas: (1) Objek kajiannya; (2 Faktor penyebab terjadinya konflik; dan (3) Strategi dalam penyelesaian konflik.

Sebuah konflik berkembang menjadi sengketa bila pihak yang merasa dirugikan telah menyatakan rasa tidak puas atau keprihatinannya, baik secara langsung kepada pihak yang dianggap sebagai penyebab kerugian atau pihak lain. Suyud Margono, 2000:85). Sengketa yang terjadi saat ini antara lain terdiri atas: (1) Sengketa tradisional (berkisar tentang keluarga, warisan dan tanah), (2) Sengketa bisnis yang rumit serta erat dengan unsur keuangan, perbankan modern, peraturan perundangan, etika, pemebuhan kontrak dan sebagainya. (3) Sengketa lingkungan yang rumit dengan masalah pembuktian ilmiah dan hubungan administrasi pusat-daerah dan (4) Sengketa tenaga kerja yang diwarnai dengan masalah hak asasi, reputasi Negara dan perhatian masyarakat internasional.

\section{Murabahah}

Murabahah adalah jual beli barang pada harga asal dengan tambahan keuntungan/ margin yang disepakati. Dalam jual beli murabahah penjual harus memberitahu harga pokok pembelian barang dan menentukan tingkat keuntungan tertentu sebagai tambahan, dan menjelaskannya kepada pembeli. (Syafii, 2001).

Murabahah merupakan salah satu bentuk jual beli dimana penjual memberikan informasi kepada pembeli tentang biaya-biaya yang dikeluarkan untuk mendapatkan komoditas (harga pokok pembelian), dan tambahan profit yang diinginkan yang tercermin dalam harga jual. Murabahah bukanlah merupakan transaksi dalam bentuk memberikan pinjaman/ kredit kepada orang lain dengan adanya penambahan interest/ bunga, akan tetapi ia merupakan jual beli komoditas (Antoni M.Syafii, 2001). Menurut pandangan ulama fiqh, (Al Kasani) Murabahah merupakan bentuk jual beli yang diperbolehkan. Murabahah mencerminkan transaksi jual beli dimana harga jual 


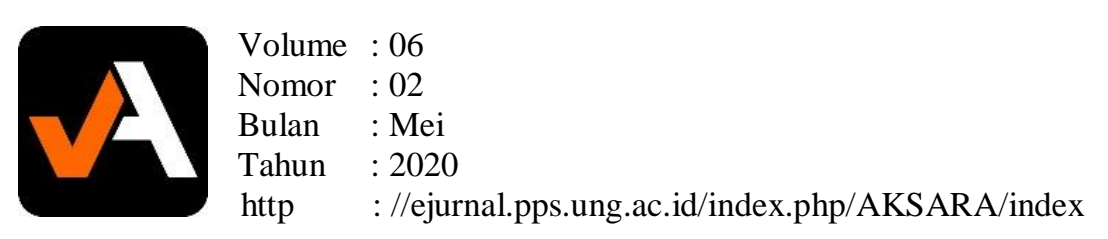

merupakan akumulasi dari biaya-biaya yang telah dikeluarkan untuk mendatangkan obyek transaksi (harga pokok pembelian) dengan tambahan keuntungan tertentu yang diinginkan penjual (margin), dimana harga beli dan jumlah keuntungan yang diinginkan diketahui oleh pembeli, dalam arti, pembeli diberitahu berapa harga belinya dan tambahan keuntungan yang diinginkan. Keabsahan dan legalitas syar'i jual beli murabahah dapat disandarkan pada keumuman firman Allah : ".. dan Allah telah menghalalkan jual beli dan mengharamkan riba...”, atau juga bisa disandarkan pada keumuman sabda Rasulullah SAW: "Sesungguhnya jual beli itu berdasarkan atas kerelaan (keridlaan)” (Ibnu Majah, nomor 2245).

Selain itu, keabsahan jual beli murabahah juga bisa disandarkan pada sebuah hadits dari Suhaib Ar Rumi r.a. bahwa Rasulullah bersabda,:

"Tiga hal yang di dalamnya terdapat keberkahan, jual beli secara tangguh, muqaradhah (mudharabah), dan mencampurkan gandum dengan tepung untuk keperluan rumah, bukan untuk dijual". (H.R. Ibnu Majah).

\section{Metode Arbiter}

Metode arbiter dalam penyelesaian sengketa adalah suatu penyelesaian perkara yang dilakukan antara salah satu pihak dengan pihak yang lainnya. Penyelesaian sengketa terdiri dari dua cara yaitu melalui litigasi (pengadilan) dan non litigasi (luar pengadilan). Di dalam Pasal 1 angka 1 Undang - Undang Nomor 30 Tahun 1999 tentang Arbitrase dan Alternatif Penyelesaian Sengketa menjelaskan bahwa penyelesaian sengketa di luar pengadilan mengenal adanya cara arbitrase yaitu penyelesaian suatu sengketa perdata di luar pengadilan yang di dasarkan pada perjanjian arbitrase yang dibuat secara tertulis oleh para pihak yang bersengketa

Menurut Pasal 1 angka 10 UU Nomor 30 Tahun 1999 tentang Arbitrase dan Alternatif Penyelesaian Sengketa, penyelesaian sengketa melalui non litigasi (luar pengadilan) terdiri dari 5 cara yaitu: (1)Konsultasi: suatu tindakan yang dilakukan antara satu pihak dengan pihak yang lain yang merupakan pihak konsultan. (2) Negosiasi: penyelesaian di luar pengadilan dengan tujuan untuk mencapai kesepakatan bersama atas dasar kerja sama yang lebih harmonis. (3)Mediasi: penyelesaian melalui perundingan untuk mencapai kesepakatan di antara para pihak dengan dibantu oleh mediator. (4) konsiliasi: penyelesaian sengketa dibantu oleh konsiliator yang berfungsi menengahi para pihak untuk mencari solusi dan mencapai kesepakatan di antara para pihak. (5) Penilaian Ahli: pendapat para ahli untuk suatu hal yang bersifat teknis dan sesuai dengan bidang keahliannya.

Selain itu juga menggunkan metode penemuan hukum Bayani (Abdul Basit muqalaf). Dalam perspektif penemuan hukum Islam dikenal juga dengan istilah penemuan hukum al-bayan mencakup pengertian al-tabayun dan tabyin, yakni: (1)Proses mencari kejelasan (azh-zhuhr), (2)Pemberian penjelasan (al-izhar), (3)Perolehan makna (al-talaqqi) dan (4)Penyampaian makna (al-tablig).

\section{METODE PENELITIAN}

Metode penelitian kualitatif dengan pendekatan penelitian yuridis normatif, yaitu penelitian yang mengacu dan berbasis pada analisa norma hukum dengan tujuan untuk menemukan kebenaran berdasarkan logika keilmuan dari sisi normatifnya. Penelitian ini menekankan pada penggunaan norma hukum secara tertulis serta didukung dengan hasil wawancara dengan beberapa narasumber. penelitian deskriptif analitis dengan memberikan gambaran mengenai fakta-fakta terkait dengan 
permasalahan penelitian. Penelitian diharapkan dapat memberikan penjelasan mengenai metode arbiter berkenaan dengan penyelesaian sengketa akad pembiayaan murabahah BS X dengan PT AS terhadap putusan Badan Arbitrase Syariah Nasional (Basyarnas). Hal ini juga dikaitkan dengan peraturan perundang-undangan yang berlaku di Indonesia, dan penerapan proses penyelesaian sengketa serta metode arbiter terhadap implementasi UU No. 30 Tahun 1999 Tentang Arbitrase dan Alternatif Penyelesaian Sengketa. Selain itu juga melalui data sekunder dengan penelaahan terhadap buku-buku kepustakaan, dan melakukan penelitian terhadap peraturan perundangan yang berkaitan dengan, hukum perbankan syariah.

\section{HASIL PENELITIAN DAN PEMBAHASAN Majelis arbiter}

Majelis arbiter dalam menyelesaikan sengketa akad murabahah antara Bank Syariah X dengan PT AS mempunyai dasar untuk mempertimbangkan, menetapkan dan memutuskan sengketa tersebut. Kaidah hukum merupakan dasar metode atau cara arbiter dalam memeriksa dan memutuskan sengketa. Pada prinsipnya, arbiter berpegang pada prinsip keadilan dan kaidah hukum, baik hukum yang terdapat di Al Aquran, Hadist, Ijma Ulama dan ditambah dengan KUH Perdata, Undang-Undang Arbitrase, Undang-Undang Perbankan Syariah, Peraturan Bank Indonesia, Fatwa Dewan Syariah Nasional, Kaidah fiqh, dan pendapat para ahli perbankan syariah.

Kaidah hukum dijadikan dasar penetapan dan pertimbangan arbiter, antara lain:

(1)Arbiter menetapkan putusan mempunyai kendala dalam menentukan nilai kerugian mengenai bukti-bukti asli laporan keuangan, klarifikasi bukti kuitansi tambahan kemudian bukti lain berupa foto, keterangan dan proses verifikasi. (2)Arbiter menggunakan asas hukum sesuai syariah Islam dan dinyatakan secara harfiah/formal berlaku. Irah-irah putusan sebelumnya atas nama negara, kini harus dilengkapi lafal sumpah demi keadilan berdasar Ketuhanan Yang Maha Esa, putusan jelas harus dijiwai keimanan dan takwa kepada Tuhan Yang Maha Esa. Pertimbangan bukan hanya sekedar kebenaran hukum dan demi mewujudkan kepastian hukum. (3)Basyarnas mempunyai kompetensi untuk menyelesaikan sengketa akad murabahah yang disepakati oleh para pihak yang tencantum dalam akad. Apabila usaha menyelesaikan sengketa terdapat perbedaan pendapat atau persepsi diselesaikan melalui musyawarah untuk mufakat tidak menghasilkan keputusan maka, kedua belah pihak sepakat untuk menunjuk dan menetapkan melalui Basyarnas. Basyarnas memberikan putusan menurut tata cara dan prosedur abitrase yang ditetapkan sesuai prosedur yang berlaku. Putusan bersifat final dan mengikat. Pertimbangan arbiter terhadap AS dan BS X, telah menundukkan diri secara sukarela dan berdasarkan ketentuan hukum untuk melakukan penyelesaian sengketa. Penyelesaian sengketa sesuai dan berdasarkan ketentuan Undang-Undang No. 21 Tahun 2008, pasal 55. Pasal 55 ayat (1) mengatur tentang penyelesaian sengketa Perbankan Syariah dilakukan oleh pengadilan dalam lingkungan Peradilan Agama. Pasal 55 ayat (2) dalam hal para pihak telah memperjanjikan penyelesaian sengketa selain sebagaimana dimaksud pada ayat (1), penyelesaian sengketa dilakukan sesuai dengan isi Akad. Pasal 55 ayat (3) Penyelesaian sengketa sebagaimana dimaksud pada ayat (2) tidak boleh bertentangan dengan Prinsip Syariah. Fatwa DSNMUI No. 04/DSN-MUI/IV/2000 Tentang Murabahah telah mencantumkan bahwa penyelesaian melalui arbitrase syariah dalam hal ini Basyarnas. Ketentuan pencantuman tersebut, jika nasabah menunda-nunda pembayaran dengan sengaja, atau jika salah satu pihak tidak menunaikan kewajibannya, maka penyelesaiannya dilakukan melalui Badan Arbitrase Syari'ah setelah tidak tercapai kesepakatan melalui musyawarah, 
Arbiter dalam memberikan putusannya berpedoman dan mengutip beberapa ayat di Al-qur an, antara lain: (a)QS. An- Nisa ayat 29, 58, 59 dan 135, (b)QS. Al-Baqarah 2 ayat 188 dan 275.

Analisa menurut KUH Per Perdata. Berdasarkan ketentuan KUH Perdata Pasal 1342 yang menyebutkan, jika kata-kata dalam suatu kontrak sudah jelas maka tidak diperkenankan untuk menyimpang daripada dengan jalan penafsiran. Arbiter mempunyai pertimbangan yang kuat terhadap perbuatan BS X merupakan wanprestasi. Arbiter mempertimbangkan bahwa, BS X telah menghentikan pembiayaan termasuk dalam wanprestasi atau cidera janji. Wanprestasi oleh BS X dalam hubungannya dengan tindakan yang dilakukan. Arbiter dalam pertimbangannya memutuskan, bahwa BS X telah melakukan cidera janji, sekalipun Akad dinyatakan tidak sah dan karena itu batal demi hukum. PT. AS telah wajib sebagai debitor mengembalikan utang kepada BS $\mathrm{X}$ sebagai kreditor.

\section{Pertimbangan Arbiter}

Pertimbangan arbiter, bahwa Pegawai BS X telah melakukan pelanggaran Standar Operasional dan Presedur (SOP). Syarat untuk dikeluarkannya SP3 dan ditandantatangani akad adalah setelah syarat administratif dipenuhi. BS X dalam pengikatannya telah sepakat terhadap halhal yang seharusnya menurut SOP Bank telah harus sesuai dengan SOP yang mengatur tentang pembiayaan karena bentuk Akad belum sempurna karena masih berbentuk waad / Janji Beli. Sehingga pendapat arbiter terhadap akad tidak sah. Selain itu arbiter juga mendasarkan pada pasal 1234 KUH Perdata menyebutkan bahwa "Perikatan ditujukan untuk memberikan sesuatu, untuk berbuat sesuatu, atau untuk tidak berbuat sesuatu." Dari maksud pasal tersebut dapat diketahui bahwa prestasi dapat dibagi menjadi beberapa model sebagaimana yang disebutkan pada Pasal 1234 KUH Perdata yaitu memberikan sesuatu, berbuat sesuatu, tidak berbuat sesuatu. Dengan demikian istilah wanprestasi dapat diartikan tidak dilaksanakan prestasi atau kewajiban sebagaimana mestinya yang dibebankan oleh kontrak terhadap pihak-pihak tertentu seperti yang disebutkan dalam kontrak yang bersangkutan. Tindakan wanprestasi membawa konsekuensi timbulnya hak bagi pihak yang dirugikan untuk menuntut pihak yang melakukan wanprestasi untuk memberikan ganti rugi, sehingga oleh hukum diharapkan agar tidak ada satu pihak pun yang dirugikan karena wanprestasi tersebut.

Pasal 1238 KUHPerdata menyebutkan bahwa, debitur dinyatakan lalai dengan surat perintah atau dengan akta sejenis itu, atau berdasarkan kekuatan dari perikatan sendiri, jika perikatan mengakibatkan debitur harus dianggap lalai dengan lewatnya waktu yang ditentukan. Dari ketentuaan pasal tersebut dapat diketahui bahwa wanprestasi dapat terjadi karena kesengajaan, kelalaian dan tanpa kesalahan yaitu tanpa kesengajaan atau kelalaian. Jika seseorang tidak melaksanakan prestasinya sesuai ketentuan dalam kontrak, maka pada umumnya dengan beberapa pengecualian tidak dengan sendirinya dia telah melakukan wanprestasi. Jika tidak ditentukan lain dalam kontrak atau dalam undang-undang, wanprestasinya si debitur terjadi setelah debitur dinyatakan lalai oleh kreditur ingebrehstelling yakni dengan dikeluarkannya suatu akta lalai oleh pihak kreditur.

Metode Arbiter Berdasarkan UU No. 30 Tahun 1999 Tentang Arbitrase dan Alternatif Penyelesaian Sengketa. Oleh karena, arbite itu telah menjalankan apa yang diatur dalam UU tersebut dengan acara pemeriksaan. Hal itu dapat dianalisa dalam proses penyelesain sengketa dasar hukum yang digunakan telah sesuai dengan hukum acara berdasarkan tata cara pemeriksaan sesuai dengan UU arbitrase. Untuk itu, tentang tata cara atau metode arbiter dalam penyelesaian sengketa telah 
sesuai dengan pasal 36 dan 37 tentang acara pemeriksaan yaitu pemeriksaan dilakukan secara tertulis, pemeriksaan secara lisan, pemeriksaan saksi dan saksi ahli diselenggarakan menurut hukum acara perdata, dilakukan di tempat kantor Basyarnas Jakarta sesuai kesepakatan para pihak. Dari hasil analisa penulis ternyata arbiter juga melakukan pemeriksaan ditempat atas barang sengketa. Pasal 38 dan 39 tentang tata cara penyampaian tuntutan dan jawaban yaitu arbiter memerintahkan PT AS menyampaikan tuntutan, berbentuk surat tuntutan, minimal isi tentang nama lengkap dan tempat tinggal para pihak, uraian singkat sengketa dilampiri bukti-bukti dan isi tuntutan. Arbiter menyampaikan salinan tuntutan kepada Bank BS X dengan perintah harus menanggapi dan memberi jawaban, secara tertulis serta paling lambat 14 hari dari tanggal penerimaan. Bersamaan dengan itu arbiter memerintahkan para pihak menghadap dimuka sidang arbitrase paling lambat 14 hari terhitung dikeluarkannya perintah tersebut, dan dalam hal ini telah dilaksanakan oleh arbiter. Arbiter sebelumnya telah menawarkan untuk perdamaian sesuai pasal 45 memperkenankan dan meminta para pihak untuk berdamai dan mengajukan proposal akta perdamaian namun dalam praktiknya proposal perdamaian tidak tercapai. Karena para pihak tidak tercapai kesepakatan untuk berdamai, maka proses dilanjutkan dengan memeriksa pokok sengketa sesuai pasal 46 maka, arbiter Arbiter telah memutuskan sesuai dengan pemeriksaan saksi dan saksi ahli yaitu pasal 49 dan sesuai pasal 50 tentang tata cara pemberian keterangan saksi ahli secara tertulis. Mengenai putusan arbiter telah sesuai dengan pasal 52 tentang pendapat yang mengikat dan terhadap pendapat mengikat yang diberikan tertutup upaya hukum apapun juga. Putusan arbiter telah sesuai dengan pasal 54 mengenai isi putusan arbitrase. Kewenangan arbiter untuk menjatuhkan putusan berdasar rasa keadilan dan kepatutan (ex aeque et bono) sesuai dengan pasal 56. Kompetensi absolut dalam menyelesaikan sengketa akad murabahah antara PT AS dengan BS X telah sesuai dengan pasal 60 yang mengatur bahwa putusan badan arbitrase syariah bersifat final dan mempunyai kekuatan hukum tetap dan mengikat para pihak (final and binding).

\section{Metode Arbiter Dalam Penyelesaian Sengketa}

Metode Arbiter Dalam Penyelesaian Sengketa dalam praktiknya untuk menyelesaikan sengketa akad murabahah menggunakan metode dan cara dengan prinsip kehati-hatian. Para Arbiter telah melakukan dan mengamati setiap bukti dan saksi-saksi untuk menyelesaikan sengketa. Penyelesaian sengketa antara BS X dengan PT AS dengan pendekatan metode menurut pendapat Ibnu Qoyyim Al Zauziah. Metode yang diterapkan dalam memutus perkara akad murabahah di Basyarnas antara lain: (1) Sebelum memulai pemeriksaan, pada saat melakukan pemeriksaan kemudian sampai dengan memutus sengketa arbiter memohon doa kepada Allah SWT untuk diberikan kekuatan, petunjuk dan keridhoanNya. (2) Dalam melakukan analisa kasus sengketa arbiter memahami bahasa dan maksud dari apa yang tertuang dalam akad serta bukti-bukti lain. Arbiter juga mempunyai keyakinan yang kuat terhadap permasalahan sengketa yang sedang diperiksa. Sesuai dengan firasat/ filing. (3) Dalam pemeriksaan juga di minta kepada para pihak bukti-bukti proses pembiayaan dari awal sampai akhir akad pembiayaan murabahah. Sesuai dengan Qorinah/bukti yang arbiter yakini. (4) Dalam persidangan juga mengudang dan meminta keterangan para saksi, saksi ahli dan menghadirkan lebih dari satu saksi dengan membandingakan serta mengkaji keterangan para ahli yang diudang. Hal ini sesuai dengan Al bayyinat (keterangan) dan Iqrar (pengakuan). (5)Para arbiter telah memiliki pengalaman lebih dari lima belas tahun dibidang hukum dan berpengalaman dalam menangani kasus sengketa di Badan Arbitrase Nasional Indonesia (BANI). Pada putusannya arbiter juga menerapkan dan berpedoman pada prinsip ex aeque et bono. 
Dalam setiap memeriksa, mempelajari sampai dengan memutus dengan prinsip syariah dan kaidah hukum. Hal ini sesuai dengan perinsip putusan menggunakan sanksi kepada salah satu pihak dengan keadilan dan kepatutanSelain itu, arbiter juga menggali dan berdasarkan dari sumber Al-Qur'an dan Hadist, Undang-Undang, Fatwa DSN, KUH Perdata dan pendapat para ahli syariah. Hal ini sesuai dengan prinsip Istidlal Bil Imarat / Mencari informasi dengan tanda-tanda. Disamping itu metode arbiter dalam menyelesaikan sengketa BS X dengan PT As telah sesuai dengan apa yang pendapat dari para ahli hukum Islam tentang metode arbiter dalam menyelesaikan sengketa Syariah. Para pelaku ekonomi syari'ah sejak awal harus berkomitmen dan patuh terhadap putusan Arbitrase sesuai dengan perjanjian atau akad yang telah disepakati sesuai UU. Nomor 30 Tahun 1999 tentang Arbitrase dan Alternatif Penyelesaian Sengketa, agar tercipta kepastian hukum dan keadilan bagi para pihak dalam kegiatan ekonomi syari'ah yang menggunakan prinsip-prinsip hukum Islam. Menurut penulis putusan arbiter dengan perbandingan yang dilakukan dalam penemuan suatu hukum antara lain, metode penemuan hukum Bayani. Dalam perspektif penemuan hukum Islam dikenal juga dengan istilah penemuan hukum al-bayan mencakup pengertian al-tabayun dan tabyin, yakni: (1)Proses mencari kejelasan (azh-zhuhr), (2)Pemberian penjelasan (al-izhar), (3)Perolehan makna (al-talaqqi) dan (4)Penyampaian makna (al-tablig).

Proses penemuan hukum yang dilakukan oleh arbiter Basyarnas dapat analisa dengan pendekatan metode bayani antara lain: Setelah melalukan wawancara salah seorang beberapa arbiter mengunakan metode interprestasi (al bayan). Arbiter mengunakan metode interprestasi Gramatikal (menurut bahasa), penafsiran kata-kata dalam teks hukum sesuai kaidah bahasa dan kaidah hukum tata bahasa. Dengan mencoba menangkap arti akad murabahah. Interprestasi historis, dengan menafsirkan akad murabahah dan cara penyelesaian sengketa dengan merujuk kepada ayat Alquran, hadist, undang-undang, fatwa dan peraturan tentang akad murabahah Interpresatasi sistematis, penafsiran akad murabahah bagian dari keseluruhan system, artinya aturan itu tidak berdiri sendiri, tetapi selalu difahami dalam kaitannya dengan jenis peraturan lainnya. Interprestasi sosiologis atau teologis, secara sosiologis/teologis apabila makna peraturan /ayat ditetapkan berdasarkan tujuan kemaslahatan.

Dengan melihat syarat dan rukun akad murabahah. Interprestasi komparatif, dimaksudkan sebagai metode penafsiran dengan jalan membandingkan (muqarona) berbagai system hukum ataupun membandingkan pendapat pendapat imam mazhab. Interprestasi futuristic, Disebut juga metode penemuan hukum yang bersifat antisipasi yaitu penjelasan ketentuan hukum dengan berpedoman pada aturan yang belum mempunyai kekuatan hukum, karena peraturannya masih dalam rancangan. Interprestasi restriktif, Metode interprestasi yang sifatnya membatasi, seperti gramatika kata "murabahah". Interprestasi ekstensif, metode penafsiran yang membuat interprestasi melebihi batas-batas hasil interprestasi gramatikal, seperti perkataan al-bai dalam fiqh muamalah oleh qadhi boleh di tafsirkan secara luas yaitu tidak saja jual beli termasuk segala peralihan hak. Interprestasi otentik, atau secara resmi, dalam melakukan interprestasi dari kejadian dengan buktibukti dan saksi-saksi yang menjadi dasar dalam memutus sengketa akad murabahah Interprestasi interdispliner, bias dilakukan dalam suatu analisis masalah yang menyangkut berbagai disiplin ilmu hukum, disini dipergunakan logika penafsiran tentang akad murabahah Interprestasi multidisipliner, seorang arbiter dengan kecerdasan membuat pengertian dan intrepretasi akad murabahah. Sehingga para arbiter dengan yakin memutuskan sengketa akad murabahah dinyatakan tidak sah dan karena itu batal demi hukum. Hal ini berdasarkan ketidaksesuaian asas prinsip perbankan syariah antara lain: Termasuk dalam hal melanggar prinsip gharar. Menurut Ikwan Abidin Basri Anggota Dewan 
Syariah Nasional- Majelis Ulama Indonesia, bahwa prinsip gharar telah dijelaskan dalam hadist, sebagai berikut: Dari Ibnu Mas'ud RA bahwasanya Rasulullah SAW berkata:

\section{“Janganlah kamu membeli ikan yang masih di dalam air ( kolam ) karena hal itu gharar”. HR. Ahmad.}

Para ulama secara umum menjelaskan arti hadis ini, dapat dikelompokkan menjadi dua kategori. Pertama, kelompok yang menafsirkan bahwa maksud jual beli gharar yang dilarang adalah jual beli di mana objek yang diperjualbelikan tidak ada, tidak dapat dihadirkan atau tidak dikuasai oleh penjual sehingga tidak dapat dihadirkan. Penafsiran ini hanya membatasi objek gharar saja (mahal al-gharar). Kelompok kedua adalah yang berpendapat bahwa jual beli gharar itu mencakup semua aspek yang mengandung gharar dan jahalah. Jadi gharar tidak hanya terjadi pada ketidakmampuan objek jual beli bisa dihadirkan atau tidak ( wujud dan 'adam), tetapi juga mencakup gharar dalam akad, dalam sifat barang dan waktu penyerahan dan lain sebagainya. Kelompok ini menjelaskan bahwa sandaran yang ada pada jual beli gharar itu bukan kepada masdar tetapi kepada sifat dari jual beli itu sendiri. Dengan demikian maka jual beli gharar dimaknai sebagai jual beli yang mengandung risiko ketidakpastian objek jual beli dapat dihadirkan, ketidakjelasan sifat dan kualitas barang yang dijual dan juga ketidakjelasan akad yang dipergunakan dalam jual beli tersebut. Singkatnya, semua bentuk jual beli yang mengadung ketidakpastian dan ketidakjelasan sehingga berpotensi menimbulkan perselisihan dan persengketaan maka hal itu termasuk jual beli gharar. Sesuai dengan hal tersebut di atas, bahwa Murabahah menekankan adanya pembelian komoditas berdasarkan permintaan nasabah, dan adanya proses penjualan kepada nasabah dengan harga jual yang merupakan kombinasi dari biaya beli dan tambahan profit yang diinginkan, sehingga terhidar dari unsur gharar. Dengan demikian, pihak bank diwajibkan untuk men-disclose (menerangkan) tentang harga beli dan tambahan keuntungan yang diinginkan kepada nasabah. Dalam konteks ini, bank tidak meminjamkan uang kepada nasabah untuk membeli komoditas tertentu, akan tetapi seharusnya pihak bank-lah yang berkewajiban untuk membelikan komoditas pesanan nasabah dari pihak ketiga, dan baru kemudian dijual kembali kepada nasabah dengan harga yang disepakati kedua pihak. Dari hasil pembuktian bahwa bank menghentian tahap kedua pembiayaan akad murabahah secara sepihak dikarenakan belum terpenuhi syarat pemenuhan Surat Izin Mendirikan Bangunan (IMB) yang merupakan kewenangan dari Pihak yang berwenang dari Pemerintah.

\section{PENUTUP}

Berdasarkan analisis tersebut di atas dan pembahasan dapat disimpulkan sebagai berikut: Metode yang digunakan oleh arbiter dalam memeriksa dan memutus akad murabahah. Dalam putusan arbiter telah sesuai dengan metode dalam menyelesaikan sengketa akad Murabahah. Arbiter Basyarnas telah menjalan peran dan fungsi dalam penyelesaiaan sengketa BS X dengan PT AS dengan putusan final dan mengikat. Ketentuan-ketentuan yang disyaratkan dalam unsur-unsur perbuatan melawan hukum (onrechtmatigedaad). Dalam menyelesaikan perkara ekonomi syari'ah antara PT AS dengan BS X adalah tepat sesuai akad perjanjian murabahah dan berdasarkan perundang-undangan. Basyarnas merupakan badan yang dapat menyelesaikan sengketa ekonomi syariah dengan memutuskan suatu keputusan hukum atas masalah yang dipersengketakan dengan cara tahkim/ menujuk arbiter dengan sistem syariah. Penetapan dan syarat menjadi arbiter yang menguasai hukum, fiqih muamalah dan perbankan syariah merupakan standar yang diperlukan di Basyarnas. 
Diperlukan pengalaman dan keilmuan oleh setiap arbiter dalam penyelesaian sengketa muamalah Islam melalui Basyarnas dimaksudkan untuk meningkatkan kinerja lembaga tersebut pada masa yang akan datang. Disamping itu metode arbiter dalam menyelesaikan sengketa BS X dengan PT AS telah sesuai dengan apa yang pendapat dari para ahli hukum Islam tentang metode arbiter dalam menyelesaikan sengeta Syariah. Para pelaku ekonomi syari'ah sejak awal harus tunduk dan patuh terhadap putusan Arbitrase sesuai dengan perjanjian atau akad yang telah disepakati sesuai UndangUndang Nomor 30 tentang Arbitrase dan Alternatif Penyelesaian Sengketa, agar tercipta kepastian hukum dan keadilan bagi para pihak dalam kegiatan ekonomi syari'ah yang menggunakan prinsipprinsip hukum Islam.

\section{DAFTAR PUSTAKA}

Abdul Basit muqalaf.2008, Wasail inha al muna zaati a, Bainal afrat fi syariatil al Islamiyah, Ibnu Qoyyim Al Zauziah, At Turuk al Hukumiyah .

Abdullah as Sattar Fatullah Sa'id.1402 H, Al Muamalat fi al Islam, Rabithal al Islami, Idarah al Kitab al Islami, Mekkah, Saudi Arabia,.

Husain Sahatah dan Siddiq Muh Al Amin Adh Dhahir.2005, Transaksi dan Etika Bisnis Islam, Visi Insani Publising.

Tim Basyarnas-MUI.2006, Profil dan Prosedur Badan Arbitrase Syariah Nasional. Antoni, Muhammad Syafii.2001, Bank Syariah: Dari Teori ke Praktek, Jakarta, GIP. Fatwa Dewan Syariah Nasional.2001,Majelis Ulama.

Fathurrahman Djamil.1994. Arbitrase Dalam Perspektif Sejarah Islam, Badan Arbitrase Muamalat Indonesia bekerjasama dengan Bank Muamalat.

Departemen Pendidikan dan Kebudayaan.1990,Kamus Besar Bahasa Indonesia, Penerbit Balai Pustaka, Jakarta,.

John.M. Echlosdan Hasan Shadily.1996, Kamus Inggris Indonesia dan Indonesia Inggris, Penerbit Gramedia,Jakarta.

Satrio.2012,Wanprestasi Menurut KUHPerdata, Doktrin dan Yurisprudensi, (Bandung: Citra Aditya Bakti,).

Suyud Margono.2000,ADR (Alternative Dispute Resolution) Dan Arbitease Proses Pelembagaan

Dan Aspek Hukum, Ghalia Indonesia, Jakarat.

Koentjaraningrat.1982, Kebudayaan Metaliteit dan Pembangunan, Gramedia, Jakarta.

HS, Salim.2010, Perkembangan Teori Dalam Ilmu Hukum, Raja Grafindo Persada, Jakarta

Sudarsono, 2002.Kamus Hukum, Cetakan ke-3, Penerbit Rineka Cipta. Jakarta.

Sutan Remy Syahdeni.2010, Perbankan Syariah, Produk-Produk dan Aspek-Aspek Hukumnya, Jaya Agung Offset.

Wirdyaningsih.2005, Bank dan Asuransi Islam di Indonesia, Jakarta : Kencana, Ikhwan A. Basri.2000, Signifikansi Gharar, jahalah dan Maysir

Kitab Undang-Undang Hukum Perdata Burgelijk Wetboek.2010, Bandung: Citra Umbara.

Undang-Undang 30 Tahun 1999 Tentang Arbitrase dan Alternatif Penyelesaian Sengketa Undang-Undang No 21 Tahun 2008 Tentang Perbankan Syariah.

Undang-undang No. 48 tahun 2009 tentang Perubahan atas Undang-Undang No. 4 tahunTentang Kekuasaan Kehakiman. 